\title{
DETERMINING THE MOST IMPORTANT FACTORS FOR SUSTAINABLE ENERGY TECHNOLOGY SELECTION IN AFRICA*
}

\author{
M.L. Barry ${ }^{1}$, H. Steyn ${ }^{2}$, and A.C. Brent ${ }^{1,3}$ \\ ${ }^{1,2}$ Graduate School of Technology Management \\ University of Pretoria, South Africa \\ ${ }^{1}$ mlb@up.ac.za, ${ }^{2}$ herman.steyn@up.ac.za, ${ }^{3}$ alan.brent@up.ac.za \\ ${ }^{3}$ Centre for Renewable and Sustainable Energy Studies \\ School of Public Management and Planning \\ Stellenbosch University, South Africa \\ acb@sun.ac.za
}

\begin{abstract}
The supply of sustainable energy is crucial for sustainable development in Africa. The aim of the study summarised in this paper is the identification, and prioritisation, of the factors that must be taken into account when selecting the most sustainable technological systems in the African context, by applying the Delphi technique. The questionnaire of the first round was based on factors already identified during a focus group exercise with energy experts. The Delphi participants were required to comment on the factors, add new factors, and rate all the factors. The results were fed back during the second round where respondents were again asked to rate the factors for feasibility, desirability, and importance. The outcome is the identification of the most important factors that can be used by decision makers to ensure better selection of sustainable energy technologies and projects. The top five prioritised factors are: Ease of maintenance and support over the life cycle of the technology; Suitable site readily available for pilot studies; Project management; Economic development; and Access to secured suitable sites for deployment.
\end{abstract}

\section{OPSOMMING}

Die verskaffing van volhoubare energie is van kritiese belang vir die volhoubare ontwikkeling van Afrika. Hierdie studie het gefokus op die identifisering en prioritisering van faktore wat in ag geneem moet word wanneer tegnologiese stelsels vir gebruik in Afrika geselekteer word. Die studie maak gebruik van die Delphi-tegniek. Die vraelys van die eerste rondte is gebaseer op die faktore wat gedurende ' $n$ fokusgroep met energiespesialiste geïdentifiseer is. Deelnemers is gevra om kommentaar te lewer op hierdie faktore, om nuwe faktore by te voeg, en om al die faktore te beoordeel. Die resultate is teruggevoer gedurende die tweede rondte van die Delphi waar deelnemers weer eens gevra is om die faktore te beoordeel in terme van uitvoerbaarheid, wenslikheid, en belangrikheid. Die uitkoms is die identifisering van die belangrikste faktore wat deur besluitnemers gebruik kan word om beter seleksie van 'n keuse van volhoubare energietegnologieë en -projekte te verseker. Die vyf belangrikste faktore is: Gemak van instandhouding en ondersteuning oor die lewensiklus van die tegnologie; geskikte liggings beskikbaar vir proefaanlegte; projekbestuur; ekonomiese ontwikkeling; en toegang tot geskikte liggings vir installasie.

*This paper was presented at the IAMOT 2008 Conference in Dubai, UAE. 


\section{INTRODUCTION}

\subsection{The energy situation in Africa}

Sustainable technologies enable humans to meet their needs with minimum impact on the environment [1]. Sustainable energy technologies imply that social, ecological, and economic factors, as well as the short and long term advantages and disadvantages of the technologies, have been taken into account. Such technologies must address the greatest challenge for sub-Saharan Africa in terms of reaching sustainable positive economic growth in order that urban growth can be accommodated, the society can be industrialised, and basic energy services can be provided in rural areas [2].

The map of the world population without electricity for 2002 and projected to 2030 is shown in Figure 1. The startling reality is that sub-Saharan Africa is the only region where electrification levels are projected to decrease rather than increase from now to 2030.

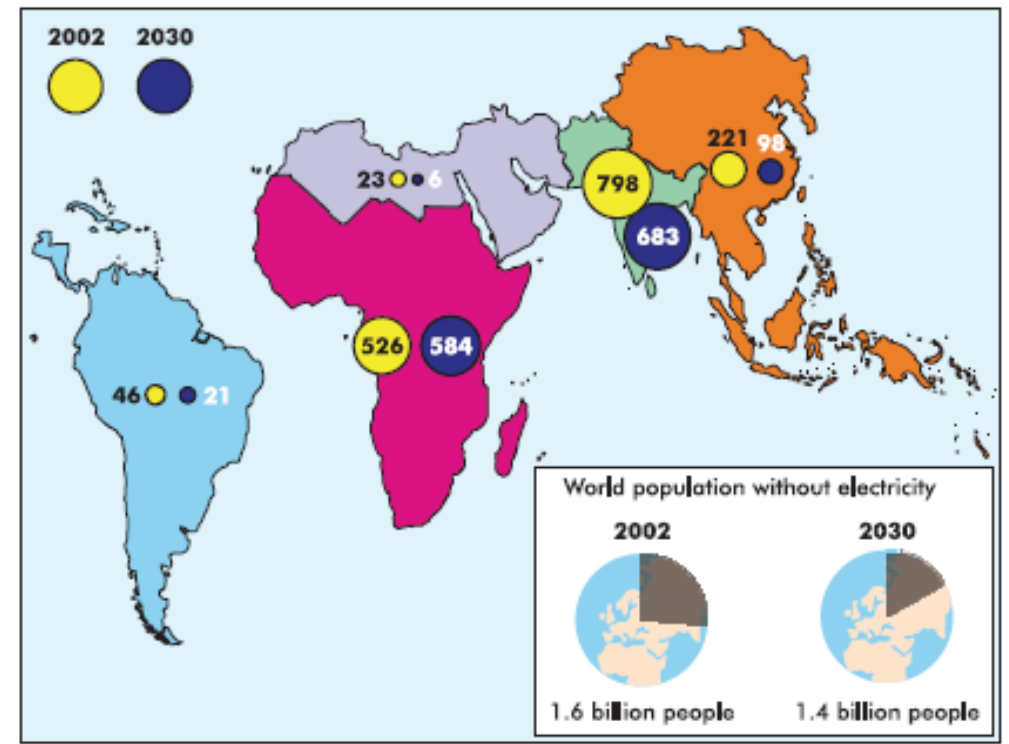

Figure 1: Electricity Deprivation (millions) [3]

Africa as a continent has the lowest per capita use of energy, mainly because there is an insufficient supply of energy, the cost of energy is too high for the majority of the population, inefficient distribution models are used, and there is a low security of supply [4].

In order to improve this situation, the use of renewable energies is advocated for the following reasons: renewable energy technologies are modular, which means that an initial low investment with incremental development is possible; the use of renewable energy technologies would imply less dependence on fossil-based fuels that need to be imported in most cases, and are subject to external price fluctuations; and diversification of energy generation contributes to energy security as long as efficient, affordable, and costeffective technologies are selected [5].

Africa has limited human and financial resources, and thus it is imperative that the technologies selected for implementation are successful. A study was undertaken in order to provide decision makers with assistance when selecting sustainable energy projects in Africa. The study consisted of a focus group, a Delphi survey, and a case study (see Figure 2). This paper addresses only the Delphi component of the study. 
According to Turoff [9], the possible objectives of a Delphi study include the determination or development of a range of possible alternatives, the exploration or exposition of underlying assumptions or information leading to differing judgements, the seeking out of information that may generate a consensus of judgements on the part of the participants, the correlation of informed judgements on topics spanning a wide range of disciplines, and the education of respondent groups as to the diverse and interrelated aspects of a topic.

There are two primary objectives for the study described in this paper:

(i) Identifying a range of possible factors that should be taken into account during the selection of sustainable energy projects in Africa; and

(ii) Prioritising the factors, taking into account the feasibility, desirability, and importance of each factor.

Some secondary objectives included the categorisation of the factors, updating the factor descriptions as determined during the focus group that preceded the Delphi study, and obtaining suitable sites for case studies for the final component of the overall study.

\subsection{The research method}

The Delphi method was originally used to forecast technological developments, like an oracle of the future; hence the name "Delphi", derived from the oracle at Delphi in Greek mythology [6]. The main advantage of the Delphi method is that participants can reconsider judgements, and that the technique is especially useful when the problem does not lend itself to precise analytical techniques [7]. Determining the factors for sustainable energy project selection in Africa fits the description of not lending itself to precise analytical techniques.

The Delphi method is summarised by Mullen [8] as a process that has a number of rounds. Feedback is given to the participants between rounds, after which they are given an opportunity to modify their responses. The responses are anonymous, and Delphi studies vary in application in panel size, composition and selection of the panel, questionnaire design, number of rounds, form of the feedback, and how consensus is treated. For a successful Delphi study, good research practice in terms of both qualitative and quantitative research should be followed [8], which includes piloting questionnaires, application of statistical techniques, etc. The Delphi design for this study is discussed in section 2.

\section{DELPHI STUDY DESIGN}

The approach that was followed is shown in Figure 2. As indicated in section 1, the Delphi study was preceded by a focus group. The objectives of the focus group were:

(i) Preliminary identification of factors that are deemed important during the selection of sustainable energy projects in Africa.

(ii) Categorisation of the identified factors.

(iii) Preliminary prioritisation of the factors.

(iv) Determination of experts who could participate in the Delphi study.

Careful consideration must be given to the nature of the research problem before deciding to use the Delphi method, as it is only appropriate for certain research problems [10]. The decision to employ the Delphi technique must be based on the appropriateness of the possible alternatives [10]. The other available techniques must also be considered. For example, if a big enough sample is available, then a comprehensive survey method must be considered. If the participants are not geographically dispersed, the interview or focus group method can be considered. 
The use of the survey, interview, or focus group method could not be used as an alternative for the Delphi method, as respondents throughout Africa and other parts of the developing world were required. The sample available was also not big enough to obtain statistically valid results when using the survey technique.

In recent literature the use of as few as two and as many as five rounds is reported [7]. The more refined the initial questionnaire, the quicker consensus can be reached, and most researchers report that the positions of the respondents are unlikely to change after two or three rounds [7]. Furthermore, repeated rounds may lead to fatigue in respondents and increased respondent attrition [8]. In this study the initial questionnaire was refined by using the factors from the focus group as an input, and thus only two rounds were required.

In the study done by Boynton [11], Delphi questions were presented via the Survey Monkey web site [12]. This allowed the respondents to access the internet when they had the opportunity, and allowed the researcher to collect the responses in an efficient and effective manner. Other electronic methods that have been used include an e-mail survey ([12]; [14]), a web-based questionnaire ([15]; [14]), and the return of surveys by fax [14]. In this study, the questionnaires for the two Delphi rounds were each implemented with the Survey Monkey tool [12]. This facilitated data gathering, as responses did not need to be manually entered into a database, thus eliminating data capture errors.

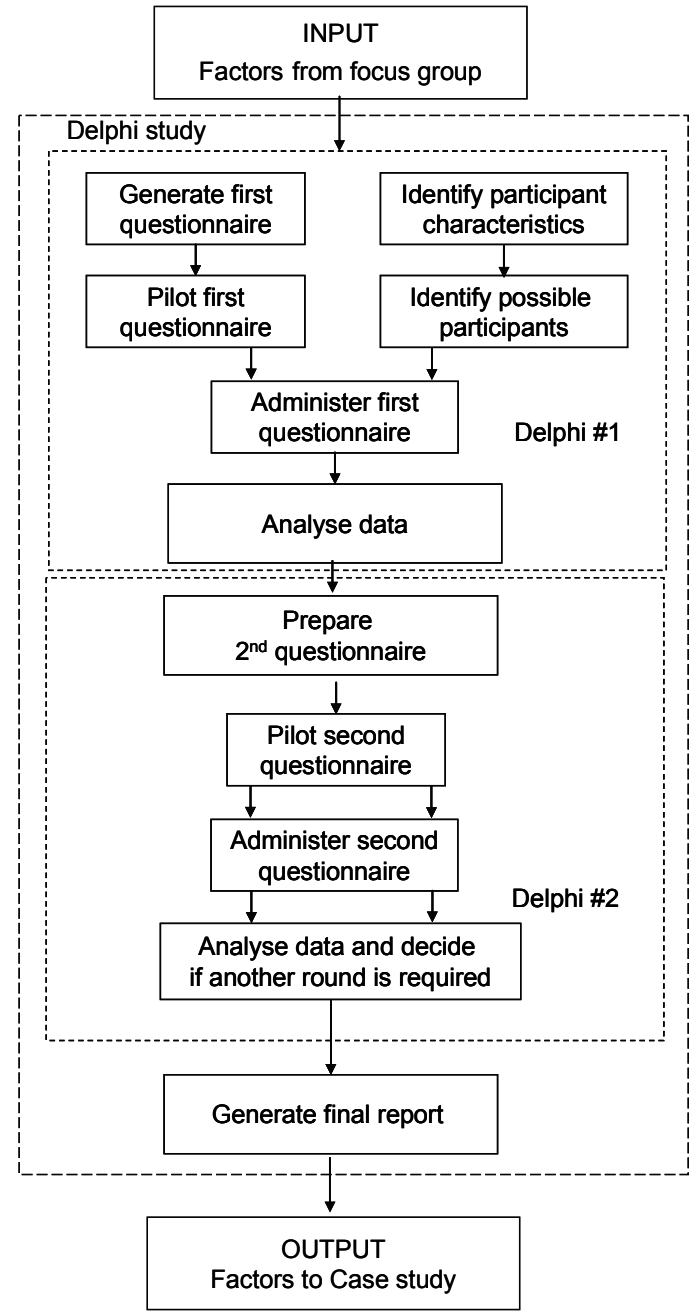

Figure 2: Block diagram of the Delphi process 


\subsection{Participant population}

The definition of an 'expert' for the Delphi process is a contentious issue in the literature. Much of Sackman's [16] criticism of the method is based on the contention that 'expert' cannot be properly defined. Definitions of an expert in the literature include: anyone with relevant input to the Delphi topic being studied [8], any individual with relevant knowledge and experience in a particular topic [17], a wide range of experts from different backgrounds as Delphi enables disagreements in a constructive forum that ensures equal participation [7], and individuals with prior experience with the issue at hand [18].

A knowledge resource nomination worksheet can be used for the selection of experts; this worksheet identifies classes of experts, first in terms of the most appropriate disciplines, organisations, and literature for obtaining experts, after which it is populated with actual names of potential experts for the Delphi [14]. In this study a knowledge resource nomination worksheet approach was used to generate 62 possible participants. The possible participants were well distributed throughout Africa and the developing world with the majority from South Africa, as shown in Figure 3. At the time of the study, experts identified in Europe were involved in establishing sustainable energy technologies in subSaharan Africa.

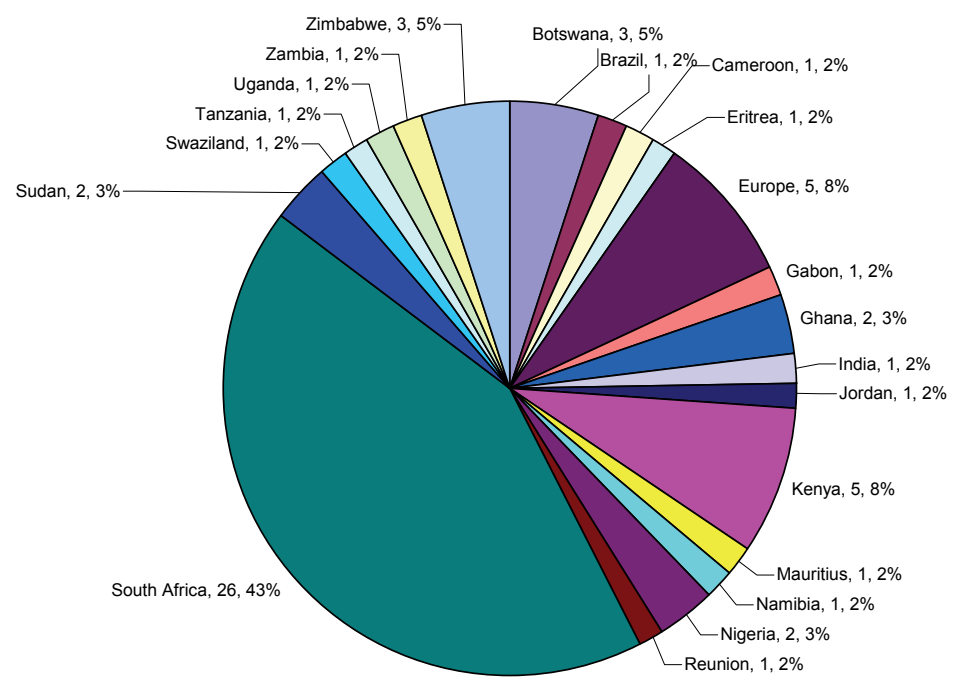

Figure 3: Geographical distribution of identified respondents

Another very contentious issue in the literature surrounding the Delphi method concerns the ideal number of the Delphi panel of participants - i.e. the sample size. The sample size should be governed by the purpose of the investigation [17]. The sizes of Delphi panels vary from three to five hundred [19], four to three thousand [17], six [12], six to twelve [8], a minimum of seven [8], seven to twelve [8], ten to fifteen [20], ten to eighteen [14], ten to fifty [9], [7], and twenty to twenty-seven [21]. Delphi studies must not be confused with conventional surveys where statistically large numbers are required for validity [8]. The optimal size seems to be between seven and thirty, as Mullen [8] states that with a panel size of smaller than seven the accuracy deteriorates, and Delbecq et al. [20] state that no further new ideas are generated once the panel exceeds thirty participants. Due to the specialised nature of the information required by this study, it was decided at the outset that a minimum of seven respondents was required during each round; this translates to a response rate of about ten percent. 
Misgivings about self-selection bias are unfounded, as no compelling differences were found between the characteristics of nominees who were willing to take part and those who were not [8].

\section{DELPHI QUESTIONNAIRES}

The development of a Delphi questionnaire should conform to professional standards for questionnaire design [8]. The materials must be well-prepared beforehand, there should be no grammatical or spelling errors in the questions or cover letter, and the task instructions should be unambiguous and thoroughly tested. The one-page covering letter should thank the individual for participating, explain why the person's inputs are required, explain how the results of the Delphi will be used, how the questionnaire is to be completed, and what the response date for the questionnaire is [20]. Guidelines recommend that the description and nature of the research should always include the identity of the researcher, the reasons why the respondent has been chosen to participate, the likely benefits of participation, and a statement on how privacy will be handled during the study [22].

\subsection{First questionnaire}

With respect to anonymity, Delphi studies can: be very rigid - i.e. the panel members are unknown to each other and to the researcher; maintain essential anonymity - i.e. the panel members are unknown to each other but known to the researcher; be not rigid - i.e. the final round consists of a face-to-face meeting; or have no anonymity, where the first round consists of a face-to-face meeting, although this is controversial [8]. In this study, respondents were anonymous to each other but not to the researcher, as this allowed the researcher to follow up with non-respondents.

In the first section of the first questionnaire, information about the study's objectives, the anonymity of respondents, the study's leaders, result distribution, the number of rounds, and the time given to complete the study were presented to the participants.

As much biographical information as possible should be obtained on each expert, and should include the number of papers published, presentations made at conferences, length of years in the field, etc [14]. In this study the following biographical information was captured: e-mail address, geographical area, type of organisation, years of experience in the energy field, publications in the energy field, highest qualification of the participant, and monetary value of projects involved in.

It has been proposed that Delphi questionnaires follow three steps. Step one involves generating as many ideas as possible; step two narrows the list down to the most important items; and step three ranks the list according to the most important factors [14]. The first step can take one of two forms: it can be broad, where participants create subcategories and variables themselves; or it can approximate survey research, where variables are already developed and the concern is only with refinement and movement towards consensus [20].

In this study, the first round questionnaire used the factors identified in the focus group as a starting point. Participants were asked to comment on the category in which a factor was placed, and the wording of a factor. Participants were also given the opportunity to add up to six new factors in each category. They were then required to rate these factors in terms of feasibility, desirability, and importance. A modified version of the five point Likert scale definitions of desirability, feasibility, and importance, as reported by Jillson [23], was used. The modified version was presented to the participant in table form, shown in

Table 1.

In some studies a self-rating of experts is included in the questionnaires. This self-rating can take many forms - for example, participants can be asked to rate their confidence in their ratings from 0 to 10 [24], and describe their knowledge in an area as awareness, 
reading, or working knowledge [8]. An evaluation of familiarity with each item may be rated as fair, good, or excellent [8], or the degree of knowledge or mastery may be rated as high, medium, or superficial for each question [25]. Ratings may be used to weigh responses or to serve as filters to determine the inclusion of respondents in subsequent rounds [8]. However, the efficacy of self-rating is disputed by Pill [8] as it is a subjective rather than an objective measure.

For this study participants were asked how pertinent their answers were to the objectives of the study, whether they were still motivated to continue, and whether the study would have value in their organisation. However, this information was not used during data analysis. On the final screen of the on-line questionnaire, participants were asked to estimate the time taken to complete the survey, and to add any other comments that they had on the study.

Piloting is essential to enable one to have a better estimate of the time that is required to complete a questionnaire [7], and to identify required revisions of the questionnaire design [26]. For example, the questionnaire can be shortened if the time taken to complete the pilot study is found to be too long, whilst still capturing the essential information [7], [23].

The first questionnaire in this study was piloted by six participants, and several changes were made to the questionnaire after the pilot. The changes were mostly to ensure that the questions were easily understood, and that there was no duplication of factors.

To ensure maximum motivation, the first questionnaire should be sent to the participants on the day that the person agrees to participate [20], [14]. A reminder letter should be sent after one week, and after that non-respondents should be telephoned [14], [7]. In this study, telephone numbers for most of the participants were not available.

The first questionnaire was sent to respondents via e-mail, together with the letter asking them to participate. Regular reminders were sent out every week of the three weeks within which the potential participants had been asked to respond. By the end of the third week, only three participants had responded. Personal reminders were then sent out to the participants outside of South Africa. Reminders were also sent to those participants who had started the survey, but had not completed it. Finally an extension to the survey was created and sent out to all the selected participants. A printable version (*.pdf) of the survey questions was also sent this time with instructions on how to fax back the results.

Walker and Selfe (as cited in [8]) refer to a response rate below $8 \%$ as unacceptable, and a $100 \%$ response rate as excellent. They recommend that for rigour a minimum of $70 \%$ is required, although there is no support for this statement. Typical response rates in the literature are $82 \%$ for round one and $57 \%$ for round two [17], $69 \%$ for round one and $71 \%$ for round two [23], or 58\% in round one and $85 \%$ in round two [7]; and in an internet survey, $39 \%$ in round one, $39 \%$ in round two, and $35 \%$ for round three. Response rates typically range between half and two-thirds of participants for each round [7]. Concerns have been expressed over bias resulting from low response rates and high attrition rates between rounds [8].

In the end, for this study seven respondents answered all the questions - a response rate of $11 \%$. The reason for the low response rate is ascribed to the fact that the questionnaire took rather long to complete and, due to the lack of telephone numbers, it was not possible to contact each respondent personally. Internet access in Africa can also be problematic, and this may well have contributed to the low response rate. 


\begin{tabular}{|c|c|c|c|}
\hline & Desirability scale & Feasibility scale & Importance scale \\
\hline 1 & $\begin{array}{ll}\text { - } & \text { Highly desirable. } \\
\text { - } & \text { Factor has positive and } \\
\text { little or no negative } \\
\text { effect on success of } \\
\text { implementation. } \\
\text { - Factor justifiable on own } \\
\text { merits. }\end{array}$ & $\begin{array}{l}\text { Highly feasible to gather } \\
\text { information during } \\
\text { proposal phase. } \\
\text { Minimum additional } \\
\text { resource required. } \\
\text { No major political } \\
\text { roadblocks in utilising } \\
\text { this factor. }\end{array}$ & $\begin{array}{l}\text { Highly relevant. First } \\
\text { order of priority. } \\
\text { Factor has direct bearing } \\
\text { on major issues for } \\
\text { technology selection. } \\
\text { - } \begin{array}{l}\text { Must be resolved, dealt } \\
\text { with, or treated. }\end{array}\end{array}$ \\
\hline 2 & $\begin{array}{l}\text { - } \text { Desirable. } \\
\text { minimum negative effect } \\
\text { on success of } \\
\text { implementation. } \\
\text { - Factor justifiable in } \\
\text { conjunction with other } \\
\text { factors. }\end{array}$ & $\begin{array}{l}\text { Feasible to gather } \\
\text { information during } \\
\text { proposal phase. } \\
\text { - Some additional resource } \\
\text { required. } \\
\text { - Some political } \\
\text { roadblocks in utilising } \\
\text { this factor. }\end{array}$ & $\begin{array}{l}\text { - Relevant factor. Second } \\
\text { order of priority. } \\
\text { - Factor has significant } \\
\text { impact on issues for } \\
\text { technology selection. } \\
\text { - Does not have to be fully } \\
\text { resolved. }\end{array}$ \\
\hline 3 & $\begin{array}{l}\text { - } \\
\text { undeither desirable nor } \\
\text { - Factor has equal positive } \\
\text { and negative effect on } \\
\text { success of } \\
\text { implementation. } \\
\text { - Factor justifiable in } \\
\text { conjunction with other } \\
\text { desirable and highly } \\
\text { desirable factors. }\end{array}$ & $\begin{array}{l}\text { - Contradictory evidence } \\
\text { that information can be } \\
\text { gathered during proposal } \\
\text { phase. } \\
\text { - Increase in resource } \\
\text { required. } \\
\text { - Political roadblocks in } \\
\text { utilising this factor. }\end{array}$ & $\begin{array}{l}\text { - May be relevant factor. } \\
\text { Third order of priority. } \\
\text { - Factor may have impact } \\
\text { on issues for technology } \\
\text { selection. } \\
\text { - May be a determining } \\
\text { factor to a major factor. }\end{array}$ \\
\hline 4 & $\begin{array}{l}\text { - } \text { Undesirable. } \\
\text { pactor has little or no } \\
\text { success of } \\
\text { implementation. } \\
\text { - Factor may be justifiable } \\
\text { in conjunction with } \\
\text { other highly desirable } \\
\text { factors. }\end{array}$ & $\begin{array}{l}\text { - Some indication that } \\
\text { information cannot be } \\
\text { gathered during proposal } \\
\text { phase. } \\
\text { - Large scale increase in } \\
\text { resource required. } \\
\text { - Major political } \\
\text { roadblocks in utilising } \\
\text { this factor. }\end{array}$ & $\begin{array}{l}\text { Factor insignificantly } \\
\text { relevant. Low order of } \\
\text { priority. } \\
\text { - Factor has no impact on } \\
\text { issues for technology } \\
\text { selection. } \\
\text { - Not a determining factor } \\
\text { to a major factor. }\end{array}$ \\
\hline 5 & $\begin{array}{l}\text { - Highly undesirable. } \\
\text { - Factor has major } \\
\text { negative effect on } \\
\text { success of } \\
\text { implementation. } \\
\text { - Not justifiable. }\end{array}$ & $\begin{array}{l}\text { - Information required } \\
\text { cannot be gathered } \\
\text { during proposal phase. } \\
\text { - Unprecedented } \\
\text { allocation of resources } \\
\text { required. } \\
\text { - Politically unacceptable. }\end{array}$ & $\begin{array}{l}\text { - Factor not relevant. No } \\
\text { priority. } \\
\text { - Factor has no impact on } \\
\text { issues for technology } \\
\text { selection. } \\
\text { - Factor should be } \\
\text { dropped. }\end{array}$ \\
\hline
\end{tabular}

Table 1: Scales for the evaluation of desirability, feasibility, and importance 


\subsection{Second questionnaire}

Results should be promptly compiled and analysed as they are returned, to ensure correct understanding and improve turn-around time [27]. The data of the first round Delphi were promptly analysed and the second questionnaire was compiled. The time to complete the second questionnaire was limited to fifteen minutes in an effort to obtain better response rates.

Apart from the feedback justification, which will be mostly numerical or statistical, some form of aggregated group response should also be included [8]. In terms of the qualitative data, Schmidt [28] advocates the consolidation of responses from the first round into one single response list, which must be verified by the participants in order to establish the validity of the list. In addition to the one sentence explanation of each factor, an explanatory glossary must be included to define and explain each factor based on the information submitted by the respondents in the first questionnaire, as well as the exact copy of the responses given by the experts to the first questionnaire [14].

In terms of statistical feedback, medians with minima, maxima, quartiles, and/or interquartile ranges are usually used, while some studies use means - often accompanied by standard deviations or ranges [8]. Other statistical data normally fed back include numerical and graphical frequency distributions [8, 16, 13], mean rank of each item for all items [14], an indication of the level of consensus using Kendall's coefficient of concordance [14], box and whisker diagrams [8], and a breakdown of how each proposition fared [27].

The second questionnaire consisted of an introduction where the background of the study, the estimated time for completion, and the due date were given. Respondents were given access to the detailed report on the first round of the Delphi study, which included the rating of each factor by each respondent, the mean, median, maximum, minimum, and histogram of each factor's rating, as well as the motivation given by each respondent for the rating of factors. Respondents were then given the opportunity to opt out of the study if they preferred.

The introduction was followed by the capturing of demographic information similar to that in the first study. This was followed by factor evaluation. In this section, the factors were presented to the respondents as rated during the first round questionnaire in terms of feasibility, desirability, and importance. The same description for the rating of each category on a five point Likert scale was used (see Table 1). Respondents could click on each factor in order to obtain a report on the results of the first round Delphi. After the factor evaluation, respondents were then asked if they wished to comment on the factor description wording.

At the end of the survey participants were asked how long it took to complete the survey. A very broad, open-ended question was then included in order to give the participants a final opportunity to summarise the entire study [27]. The participants were also asked to give any comments on the study as a whole. As indicated in section 1 , the next phase of this study involved a case study to validate the factors identified through the focus group and the Delphi study. For this reason, respondents were asked to recommend suitable sites for the case study.

The second round questionnaire was piloted with four participants with a profile similar to those who had piloted the first round questionnaire. No changes to the questionnaire were recommended during the pilot study.

The second round should be sent to everyone originally nominated, regardless of whether they participated in the first round, since individuals may be uncomfortable with openended questions [27]. Regular reminders were sent out during the two weeks that were allocated for the participants to complete the questionnaires. At the end of the allocated 
time, only five respondents had completed the questionnaire. An e-mail reminder was once again sent to the respondents outside of South Africa and, where telephone numbers were available, the respondents in South Africa were reminded telephonically. This resulted in eight respondents completing the questionnaire - a response rate of $13 \%$.

\section{RESULTS}

Propositions are usually judged against desirability, feasibility, importance, and confidence [7]. The key measures are reported to be feasibility and reliability, with importance used as a check for final recommendations [7]. In order to force respondents to take a stance, at least two of these measures should be used, and the scale used should not contain neutral points [9].

In the study of Jillson [23], ratings on feasibility and desirability were translated into group scores by summing the scale values and dividing the total by the number of ratings. This procedure treats nominal scales as interval data. By reviewing the frequency distribution and scale scores, Jillson was able to identify significant voting differences between those who rated themselves experts and those who did not. The issue of when to halt iterations is determined by two objective statistical criteria - namely, strong consensus (i.e. larger than 0.7 , measured by using a consensus index), or the absence of strong consensus, when the consensus index stabilises [29].

The list of issues must be reduced by eliminating the issues not selected by the majority of the respondents, and the list of issues should then be meaningfully ranked. This means that the list must be bounded statistically rather than arbitrarily, or else the mean ranks will show little variation [28]. The panel of experts must be well described in order to give the reader the tools to judge the reliability and relevance of the panel; and the response rate for the initial call must be given, as well as the number of panellists for each round, so that the relevant statistics can be confirmed and indications of flagging of interest can be highlighted [28].

\subsection{First questionnaire}

Most of the respondents who completed the first questionnaire, including the factor evaluation, were from Africa, and 1 (9\%) was from South America. Africa and South America are both seen as third world continents, so the respondent from South America can share lessons learned from that continent that will also be applicable to Africa. The majority of participants $(73 \%)$ operate at macro level, and $27 \%$ operate at micro level. The majority of respondents were from research organisations or universities $(28 \%)$, followed by three groups of $18 \%$ each who are project developers and implementers, government employees, and energy consultancy firm employees. There were two groups with $9 \%$ of respondents each from petrochemical companies and electricity utilities.

The total years of experience in the energy field amounts to 201, with an average of 20.5, a minimum of 10 , and a maximum of 38 . This means that the respondents have much experience in the energy field. Respondents were asked how many publications they have in the field of energy. Publications include journal papers, conference papers, and books. Three respondents did not answer this question, with one indicating that he/she had lost count. Of those who did respond, the total number of publications is 373 , with an average of 41.5 , the minimum 3 , and the maximum 135 . This indicated that by and large the panel was respected by their peers in the field. The majority of respondents $(55 \%)$ have a Masters degree, followed by $27 \%$ with PhDs, and $18 \%$ with Bachelors degrees.

The projects in which the respondents are involved vary: four of the respondents are involved in projects worth between US\$1 million and US\$10 million, while one respondent $(10 \%)$ is involved in projects worth more than US\$1 billion. 
The means for feasibility, desirability, and importance of all the factors, as determined during the first round Delphi, are summarised in Table 2.

\begin{tabular}{|c|c|c|c|c|}
\hline $\begin{array}{l}\text { Factor } \\
\text { Number }\end{array}$ & Short description & Feasibility & Desirability & Importance \\
\hline $\mathrm{T} 2$ & $\begin{array}{l}\text { Ease of maintenance and support over the } \\
\text { life cycle of the technology }\end{array}$ & 1.56 & 1.78 & 1.56 \\
\hline SS3 & $\begin{array}{l}\text { Suitable site readily available for pilot } \\
\text { studies }\end{array}$ & 1.71 & 1.71 & 1.43 \\
\hline 14 & Compliance for green funding & 1.71 & 1.86 & 2.29 \\
\hline $\mathrm{T} 1$ & $\begin{array}{l}\text { Maturity or proven track record of } \\
\text { technology in the world }\end{array}$ & 1.78 & 1.78 & 1.89 \\
\hline 13 & Positive Environmental Impact Assessment & 1.86 & 1.71 & 1.57 \\
\hline E4 & $\begin{array}{l}\text { Reliability of energy supply in the African } \\
\text { context }\end{array}$ & 1.89 & 1.78 & 1.56 \\
\hline 15 & $\begin{array}{l}\text { Degree of environmental impact of the } \\
\text { technology }\end{array}$ & 1.89 & 2.00 & 1.56 \\
\hline $\mathrm{A} 1$ & Project Management & 2.00 & 1.50 & 1.67 \\
\hline A2 & Human resource capacity & 2.00 & 1.67 & 1.67 \\
\hline E6 & Availability of finance & 2.00 & 1.71 & 1.71 \\
\hline T6 & Must match available resources & 2.11 & 1.67 & 1.67 \\
\hline SS1 & $\begin{array}{l}\text { Local champion to continue after } \\
\text { implementation }\end{array}$ & 2.14 & 1.71 & 2.00 \\
\hline 12 & $\begin{array}{l}\text { Must contribute to, not detract from } \\
\text { national energy security }\end{array}$ & 2.14 & 1.86 & 1.86 \\
\hline T3 & $\begin{array}{l}\text { Ease of transfer of knowledge and skills to } \\
\text { relevant people in Africa }\end{array}$ & 2.22 & 1.89 & 1.78 \\
\hline E1 & $\begin{array}{l}\text { Implementation of technology must be } \\
\text { profitable }\end{array}$ & 2.29 & 1.71 & 1.57 \\
\hline SS2 & Adoption by community & 2.29 & 1.71 & 1.71 \\
\hline I1 & Does it fit under national priorities? & 2.29 & 1.86 & 2.14 \\
\hline S1 & Create employment/ not eliminate jobs & 2.43 & 2.14 & 2.43 \\
\hline A5 & Political capacity & 2.50 & 1.83 & 1.67 \\
\hline T5 & $\begin{array}{l}\text { Replicability (i.e. the possibility of up- } \\
\text { scaling) }\end{array}$ & 2.56 & 2.11 & 2.00 \\
\hline E5 & $\begin{array}{l}\text { Existence of tax and other financial } \\
\text { incentives }\end{array}$ & 2.57 & 1.57 & 1.71 \\
\hline S3 & $\begin{array}{l}\text { Local labour used and new industries } \\
\text { created }\end{array}$ & 2.57 & 1.71 & 1.57 \\
\hline A4 & Financial capacity & 2.67 & 1.83 & 1.50 \\
\hline T4 & $\begin{array}{l}\text { Synergy of technology with other available } \\
\text { technologies }\end{array}$ & 2.67 & 1.89 & 2.11 \\
\hline A3 & Technological capacity & 2.67 & 2.17 & 2.00 \\
\hline E7 & $\begin{array}{l}\text { Possibility of equity financing by local } \\
\text { partners }\end{array}$ & 2.71 & 1.71 & 2.43 \\
\hline E2 & Economic development & 2.71 & 2.14 & 2.29 \\
\hline E3 & Synergy with other types of projects & 2.83 & 2.50 & 2.33 \\
\hline S2 & $\begin{array}{l}\text { Share holding equity - income for more } \\
\text { than one sector of the economy }\end{array}$ & 3.00 & 2.00 & 2.57 \\
\hline SS4 & Access to suitable sites can be secured & New factor & New factor & New fact \\
\hline
\end{tabular}

Table 2: Factors sorted in terms of feasibility, desirability, and importance 
An updated scoring system (see Table 3), based on the system applied by Jillson [23], was used to evaluate the factors. No factors were rated to be of indeterminate importance or indeterminate desirability, infeasible, highly infeasible, undesirable, highly undesirable, unimportant, or highly unimportant.

\begin{tabular}{|c|c|c|c|}
\hline Mean value & Feasibility & Desirability & Importance \\
\hline Less than 1.8 & $\begin{array}{l}\text { Highly } \\
\text { feasible }\end{array}$ & $\begin{array}{c}\text { Highly } \\
\text { desirable }\end{array}$ & Highly important \\
\hline $\begin{array}{l}\text { Less than } 2.6 \text { and } \\
\text { equal to or greater than } 1.8\end{array}$ & Feasible & Desirable & Important \\
\hline $\begin{array}{l}\text { Less than } 3.4 \text { and } \\
\text { equal to or greater than } 2.6\end{array}$ & $\begin{array}{l}\text { Neither } \\
\text { feasible nor } \\
\text { infeasible }\end{array}$ & $\begin{array}{c}\text { Neither } \\
\text { desirable nor } \\
\text { undesirable }\end{array}$ & $\begin{array}{l}\text { Neither } \\
\text { important nor } \\
\text { unimportant }\end{array}$ \\
\hline $\begin{array}{l}\text { Less than } 4.2 \text { and } \\
\text { equal to or greater than } 3.4\end{array}$ & Infeasible & Undesirable & Unimportant \\
\hline Less than 4.2 & $\begin{array}{c}\text { Highly } \\
\text { infeasible }\end{array}$ & $\begin{array}{c}\text { Highly } \\
\text { undesirable }\end{array}$ & $\begin{array}{c}\text { Highly } \\
\text { unimportant }\end{array}$ \\
\hline
\end{tabular}

Table 3: Scoring system for prioritisation

A summary of the number of factors that were rated highly feasible is shown in terms of desirability and importance in Table 4. No factors were rated to be of indeterminate importance or indeterminate desirability. The highly feasible factors with high desirability, high importance, or importance are shown in Table 5.

\begin{tabular}{|c|c|c|c|}
\hline & Highly important & Important & $\begin{array}{c}\text { Indeterminate } \\
\text { importance }\end{array}$ \\
\hline Highly desirable & 3 & 1 & 0 \\
\hline Desirable & 0 & 1 & 0 \\
\hline $\begin{array}{c}\text { Indeterminate } \\
\text { desirability }\end{array}$ & 0 & 0 & 0 \\
\hline
\end{tabular}

Table 4: Summary of desirability and importance ratings for highly feasible factors

\begin{tabular}{|c|c|c|c|}
\hline $\begin{array}{c}\text { Factor } \\
\text { No }\end{array}$ & Short description & $\begin{array}{c}\text { Highly desirable } \\
\text { and highly } \\
\text { Important }\end{array}$ & $\begin{array}{c}\text { Highly } \\
\text { desirable and } \\
\text { Important }\end{array}$ \\
\hline SS3 & $\begin{array}{c}\text { Suitable site readily available } \\
\text { for pilot studies }\end{array}$ & $\mathrm{X}$ & $\mathrm{X}$ \\
\hline $\mathrm{T} 1$ & $\begin{array}{c}\text { Maturity or proven track record of } \\
\text { technology in the world }\end{array}$ & $\mathrm{X}$ & \\
\hline $\mathrm{T} 2$ & $\begin{array}{c}\text { Ease of maintenance and support } \\
\text { over the life cycle of the technology }\end{array}$ & \\
\hline
\end{tabular}

Table 5: Factors rated highly feasible, highly desirable, highly important, or important

A summary of the number of factors that were rated feasible is shown in terms of desirability and importance in Table 6./ No factors were rated to be of indeterminate importance or indeterminate desirability. The feasible factors with high desirability, high importance, desirability, or importance are shown in Table 7. These factors are evenly distributed amongst the factor categories. 


\begin{tabular}{|c|c|c|c|}
\hline & Highly important & Important & $\begin{array}{c}\text { Indeterminate } \\
\text { importance }\end{array}$ \\
\hline Highly desirable & 1 & 1 & 0 \\
\hline Desirable & 3 & 4 & 0 \\
\hline Indeterminate desirability & 0 & 0 & 0 \\
\hline
\end{tabular}

Table 6: Summary of desirability and importance ratings for feasible factors

\begin{tabular}{|c|c|c|c|c|c|}
\hline $\begin{array}{l}\text { Fact } \\
\text { or No }\end{array}$ & Short description & $\begin{array}{l}\text { Highly } \\
\text { desirable } \\
\text { and } \\
\text { Highly } \\
\text { Important } \\
\end{array}$ & $\begin{array}{c}\text { Highly } \\
\text { desirable } \\
\text { and } \\
\text { Important }\end{array}$ & $\begin{array}{l}\text { Desirable } \\
\text { and } \\
\text { Highly } \\
\text { important }\end{array}$ & $\begin{array}{l}\text { Desirable } \\
\text { and } \\
\text { Important }\end{array}$ \\
\hline A1 & Project management & $x$ & & & \\
\hline A2 & Human resource capacity & $\mathrm{x}$ & & & \\
\hline E1 & $\begin{array}{l}\text { Implementation of } \\
\text { technology must be } \\
\text { profitable }\end{array}$ & $\mathrm{X}$ & & & \\
\hline E4 & $\begin{array}{l}\text { Reliability of energy } \\
\text { supply in the African } \\
\text { context }\end{array}$ & $\mathrm{x}$ & & & \\
\hline E5 & $\begin{array}{l}\text { Existence of tax and other } \\
\text { financial incentives }\end{array}$ & $\mathrm{X}$ & & & \\
\hline E6 & Availability of finance & $x$ & & & \\
\hline 13 & Positive EIA & $x$ & & & \\
\hline S3 & $\begin{array}{l}\text { Local labour used and new } \\
\text { industries created }\end{array}$ & $x$ & & & \\
\hline SS1 & $\begin{array}{l}\text { Local champion to } \\
\text { continue after } \\
\text { implementation }\end{array}$ & & $\mathrm{X}$ & & \\
\hline SS2 & Adoption by community & $\mathrm{x}$ & & & \\
\hline T6 & $\begin{array}{l}\text { Must match available } \\
\text { resources }\end{array}$ & $x$ & & & \\
\hline T3 & $\begin{array}{l}\text { Ease of transfer of } \\
\text { knowledge and skills to } \\
\text { relevant people in Africa }\end{array}$ & & & $\mathrm{X}$ & \\
\hline A5 & Political capacity & & & $\mathrm{X}$ & \\
\hline 15 & $\begin{array}{l}\text { Degree of environmental } \\
\text { impact of the technology }\end{array}$ & & & $\mathrm{x}$ & \\
\hline 11 & $\begin{array}{c}\text { Does it fit under national } \\
\text { priorities? }\end{array}$ & & & & $x$ \\
\hline S1 & $\begin{array}{l}\text { Create employment/ not } \\
\text { eliminate jobs }\end{array}$ & & & & $\mathrm{X}$ \\
\hline T5 & $\begin{array}{l}\text { Replicability (i.e. the } \\
\text { possibility of up-scaling) }\end{array}$ & & & & $\mathrm{X}$ \\
\hline
\end{tabular}

Table 7: Factors rated feasible, highly desirable, highly important, desirable, or important 
A summary of the number of factors that were rated neither feasible nor infeasible is shown in terms of desirability and importance in Table 8.

\begin{tabular}{|c|c|c|c|}
\hline & $\begin{array}{c}\text { Highly } \\
\text { important }\end{array}$ & Important & $\begin{array}{c}\text { Indeterminate } \\
\text { importance }\end{array}$ \\
\hline Highly desirable & 0 & 1 & 0 \\
\hline Desirable & 1 & 6 & 0 \\
\hline Indeterminate desirability & 0 & 0 & 0 \\
\hline
\end{tabular}

Table 8: Summary of desirability and importance ratings for factors with indeterminate feasibility

The feasibility of seven factors was indeterminable. The reason for this was either due to polarisation (A4, $A 3$, and E7) as some respondents rated the factor feasible while others rated it infeasible, or that those are truly indeterminate as the modal response is neither desirable nor undesirable (3). The distribution of these indeterminable factors is shown in Table 9.

During the first round, the factors were also categorised and the factor descriptions updated according to the comments made by the respondents. However, this information is not shown here as these were secondary objectives of the study.

\begin{tabular}{|l|l|r|r|r|r|r|c|c|}
\hline Number & \multicolumn{1}{|c|}{ Description } & Very high & High & Indeterminate & \multicolumn{1}{c|}{ Low } & Very low & Mode & Mean \\
\hline A4 & Financial capacity & $16.67 \%$ & $33.33 \%$ & $16.67 \%$ & $33.33 \%$ & $0.00 \%$ & 2 & 2.666667 \\
\hline T4 & $\begin{array}{l}\text { Synergy of technology with other available } \\
\text { technologies }\end{array}$ & $0.00 \%$ & $33.33 \%$ & $66.67 \%$ & $0.00 \%$ & $0.00 \%$ & 3 & 2.666667 \\
\hline A3 & Technological capacity & $0.00 \%$ & $50.00 \%$ & $33.33 \%$ & $16.67 \%$ & $0.00 \%$ & 2 & 2.666667 \\
\hline E7 & Possibility of equity financing by local partners & $14.29 \%$ & $28.57 \%$ & $28.57 \%$ & $28.57 \%$ & $0.00 \%$ & 2 & 2.714286 \\
\hline I4 & Compliance for green funding & $14.29 \%$ & $28.57 \%$ & $28.57 \%$ & $28.57 \%$ & $0.00 \%$ & 3 & 2.714286 \\
\hline E2 & Economic development & $14.29 \%$ & $14.29 \%$ & $57.14 \%$ & $14.29 \%$ & $0.00 \%$ & 3 & 2.714286 \\
\hline E3 & Synergy with other types of projects & $0.00 \%$ & $14.29 \%$ & $71.43 \%$ & $0.00 \%$ & $0.00 \%$ & 3 & 2.833333 \\
\hline S2 & $\begin{array}{l}\text { Share holding equity - income for more than one } \\
\text { sector of the economy }\end{array}$ & $0.00 \%$ & $28.57 \%$ & $42.86 \%$ & $28.57 \%$ & $0.00 \%$ & 3 & 3 \\
\hline
\end{tabular}

Table 9: Distribution of indeterminable factors

\subsection{Second questionnaire}

Of the eight respondents who completed the survey, seven $(87 \%)$ were from Africa and one (13\%) was from South America. The micro to macro level representation changed from $27: 73$ to $50: 50$. The number of types of organisations decreased, while the number of research organisation or university participants increased by 1 to 4 ; there were no petrochemical, developers/implementers, or government respondents. The number of energy (electrical utility) respondents increased by 1 to 2 . The number and percentage of respondents per type of organisation is shown in Table 4.

Energy

(electricity), 2,

$25 \%$

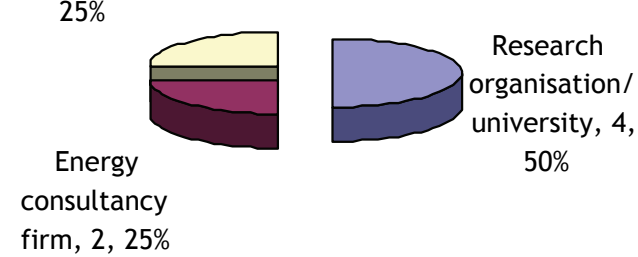

Figure 4: Number and \% of respondents per type of organisation 
The total years of experience in the energy field came to 181, with an average of 22.6, a minimum of 10 , and a maximum of 32.8. This means that on average the respondents in the second round had similar experience to those in the first round. The total number of publications is 239 , the average 28.8 , the minimum 10 , and the maximum 70 . This, again, indicated that by and large the panel is respected by their peers in the field. The majority of respondents $(50 \%)$ had PhDs, followed by $25 \%$ with Masters and $25 \%$ with Bachelor's degrees. The projects of the respondents vary from one respondent having projects worth less than $\$ 100,000$, to two respondents having projects worth between $\$ 100$ million and $\$ 1$ billion.

None of the factors scored highly feasible in the second round Delphi questionnaire. A summary of the desirability and importance ratings of the factors that scored feasible is shown in Table 10. The eleven factors that scored feasible, highly desirable, and highly important are shown in Table 11.

\begin{tabular}{|c|c|c|c|}
\hline & $\begin{array}{c}\text { Highly } \\
\text { important }\end{array}$ & Important & $\begin{array}{c}\text { Indeterminate } \\
\text { importance }\end{array}$ \\
\hline Highly desirable & 11 & 9 & 0 \\
\hline Desirable & 1 & 4 & 0 \\
\hline Indeterminate desirability & 0 & 0 & 0 \\
\hline
\end{tabular}

Table 10: Summary of desirability and importance ratings for feasible factors

\begin{tabular}{|l|c|l|l|l|}
\hline Number & \multicolumn{1}{|c|}{ Short description } & Feasibility & Desirability & Importance \\
\hline T2 & $\begin{array}{c}\text { Ease of maintenance and support over } \\
\text { the life cycle of the technology }\end{array}$ & 2.000 & 1.000 & 1.250 \\
\hline SS3 & $\begin{array}{c}\text { Suitable site readily available } \\
\text { for pilot studies }\end{array}$ & 2 & 1.625 & 1.75 \\
\hline A1 & Project management & 2.125 & 1.375 & 1.375 \\
\hline E2 & Economic development & 2.125 & 1.5 & 1.625 \\
\hline SS4 & Access to suitable sites can be secured & 2.125 & 1.625 & 1.625 \\
\hline A3 & Technological capacity & 2.25 & 1.25 & 1.5 \\
\hline SS1 & $\begin{array}{c}\text { Local champion to continue after } \\
\text { implementation }\end{array}$ & 2.25 & 1.375 & 1.375 \\
\hline T3 & $\begin{array}{c}\text { Ease of transfer of knowledge and skills } \\
\text { to relevant people in Africa }\end{array}$ & 2.25 & 1.75 & 1.5 \\
\hline SS2 & Adoption by community & 2.375 & 1.625 & 1.75 \\
\hline E6 & Availability of finance & 2.5 & 1.625 & 1.75 \\
\hline A4 & Financial capacity & 2.5 & 1.75 & 1.5 \\
\hline
\end{tabular}

Table 11: Factors rated "feasible", "highly desirable", and "highly important" 
The ten factors that scored feasible and highly important, and desirable or highly desirable and important, are shown in Table 12.

\begin{tabular}{|c|c|c|c|}
\hline Number & Short description & $\begin{array}{c}\text { Desirable and } \\
\text { highly important }\end{array}$ & $\begin{array}{c}\text { Highly desirable } \\
\text { and important }\end{array}$ \\
\hline E1 & $\begin{array}{c}\text { Implementation of technology } \\
\text { must be profitable }\end{array}$ & $\mathrm{X}$ \\
\hline I2 & $\begin{array}{c}\text { Reliability of energy supply in the } \\
\text { African context }\end{array}$ & $\begin{array}{c}\text { Must contribute to, not detract } \\
\text { from national energy security }\end{array}$ & $\mathrm{X}$ \\
\hline I3 & $\begin{array}{c}\text { Positive } \\
\text { ElA }\end{array}$ & $\mathrm{X}$ \\
\hline I5 & $\begin{array}{c}\text { Degree of environmental impact of } \\
\text { the technology }\end{array}$ & $\mathrm{X}$ \\
\hline S1 & $\begin{array}{c}\text { Create employment/ } \\
\text { not eliminate jobs }\end{array}$ & $\mathrm{X}$ \\
\hline S3 & $\begin{array}{r}\text { Local labour used and new } \\
\text { industries created }\end{array}$ & $\mathrm{X}$ \\
\hline T1 & $\begin{array}{c}\text { Maturity or proven track record of } \\
\text { technology in the world }\end{array}$ & $\mathrm{X}$ \\
\hline T4 & $\begin{array}{c}\text { Synergy of technology with other } \\
\text { available technologies }\end{array}$ & $\mathrm{X}$ \\
\hline T5 & $\begin{array}{r}\text { Replicability } \\
\text { (i.e. the possibility of up-scaling) }\end{array}$ & & \\
\hline
\end{tabular}

Table 12: Factors rated "feasible" and "highly desirable", and "important" or "highly important" and "desirable"

The feasibility of five factors and the importance of one factor were indeterminable. The reason for this was either due to polarization as some respondents rated the factor feasible while others rated it infeasible, or that those are truly indeterminate as the modal response is neither desirable nor undesirable. The distributions of these indeterminable factors are shown in Table 13. This means that there is no consensus on factor A4: Human resource capacity. At the outset the decision was made to implement only two Delphi rounds. The fact that there is only lack of consensus on one of the factors supports this decision.

\begin{tabular}{|c|c|c|c|c|c|c|c|}
\hline \multicolumn{2}{|c|}{ Factors indeterminate in terms of feasibility } & \multirow{2}{*}{\begin{tabular}{|c|} 
Very high \\
$0.0 \%$
\end{tabular}} & \multirow{2}{*}{\begin{tabular}{|l|} 
High \\
$50.0 \%$ \\
\end{tabular}} & \multicolumn{2}{|c|}{ Indetermir Low } & \multirow{2}{*}{$\begin{array}{r}\text { Very low } \\
0.0 \% \\
\end{array}$} & \multirow{2}{*}{$\frac{\text { Mode }}{2}$} \\
\hline$A 2$ & Human resource capacity & & & $25.0 \%$ & $25.0 \%$ & & \\
\hline I4 & Compliance for green funding & $0.0 \%$ & $25.0 \%$ & $62.5 \%$ & $12.5 \%$ & $0.0 \%$ & 3 \\
\hline S2 & $\begin{array}{l}\text { Share holding equity - income for more than one sector } \\
\text { of the economy }\end{array}$ & $0.0 \%$ & $0.0 \%$ & $100.0 \%$ & $0.0 \%$ & $0.0 \%$ & 3 \\
\hline E7 & Possibility of equity financing by local partners & $0.0 \%$ & $12.5 \%$ & $62.5 \%$ & $25.0 \%$ & $0.0 \%$ & 3 \\
\hline A5 & Political capacity & $0.0 \%$ & $62.5 \%$ & $62.5 \%$ & $25.0 \%$ & $0.0 \%$ & 3 \\
\hline \multicolumn{8}{|c|}{ Factors indeterminate in terms of importance } \\
\hline S2 & $\begin{array}{l}\text { Share holding equity - income for more than one sector } \\
\text { of the economy }\end{array}$ & $12.5 \%$ & $12.5 \%$ & $62.5 \%$ & $12.5 \%$ & $0.0 \%$ & 3 \\
\hline
\end{tabular}

Table 13: Distribution of indeterminable factors 
It is interesting to note that none of the respondents to the second round Delphi wanted to comment on the descriptions of the factors. Sites for suitable case studies were also identified during the second round Delphi by the respondents.

\section{CONCLUSIONS AND RECOMMENDATIONS}

The response rates in this study were low, with a response rate of $11 \%$ for the first round, followed by a response rate of $13 \%$ in the second round. However, due to the facts that the first questionnaire was informed by outputs from a focus group, and that the Delphi study will be followed by a case study to confirm the factors identified, the integrity of the study is not in question. The demographic information on the experts also points to the fact that highly qualified respondents participated.

The eleven most important factors are listed in order of priority in

Table 11. The top five factors identified in this study are: Ease of maintenance and support over the life cycle of the technology; Suitable site readily available for pilot studies; Project management; Economic development; Access to suitable sites can be secured. The descriptions of these top five factors are shown in Table 14.

\begin{tabular}{|c|c|c|}
\hline Number & Short Description & Full description \\
\hline T2 & $\begin{array}{c}\text { Ease of maintenance and } \\
\text { support over the life cycle } \\
\text { of the technology }\end{array}$ & $\begin{array}{c}\text { Ease of maintenance and support means that } \\
\text { the security of supply is enhanced. It also } \\
\text { implies that spares are affordable and can be } \\
\text { easily acquired. }\end{array}$ \\
\hline SS3 & $\begin{array}{c}\text { Suitable site readily } \\
\text { available for pilot studies }\end{array}$ & $\begin{array}{c}\text { Pilot studies are necessary to demonstrate } \\
\text { the technology to decision makers. }\end{array}$ \\
\hline E2 & Project management & $\begin{array}{c}\text { This relates to the performing organisation } \\
\text { having the project management capacity and } \\
\text { procedures in place to ensure that the } \\
\text { implementation of the technology can be } \\
\text { done successfully. }\end{array}$ \\
\hline SS4 & $\begin{array}{c}\text { Access to suitable sites can } \\
\text { be secured }\end{array}$ & $\begin{array}{r}\text { Access to sites where the technology can be } \\
\text { implemented must be secured up front. }\end{array}$ \\
\hline
\end{tabular}

Table 14: Full descriptions of top five factors identified

This Delphi study was followed by case study research to validate the factors that were identified and prioritised in the Delphi study. The case study research focused on determining which factors were taken into account when selecting sustainable energy projects in Africa, and also on determining whether information was available at project selection for the top factors that were identified in the Delphi study.

\section{ACKNOWLEDGEMENTS}

The authors acknowledge the services of researchers in the Department of Statistics at the University of Pretoria who assisted with the data analysis. 


\section{REFERENCES}

[1] Perdan, S. 2004. Introduction to sustainable development. John Wiley and Sons.

[2] UNECA 2007. Making Africa's power sector sustainable: An analysis of power sector reforms in Africa. Addis Ababa, Ethiopia: UNESCO. Available from:

http://www.uneca.org/eca_programmes/nrid/pubs/PowerSectorReport.pdf [Accessed: 19 March 2008]

[3] IEA 2004. World energy outlook 2004. International Energy Agency. Available from: http://www.iea.org/textbase/nppdf/free/2004/weo2004.pdf. [Accessed 19 March 2008]

[4] UNEA 2007. Energy for sustainable development: Policy options for Africa [online]. UN-Energy/Africa. Available from:

http://www.uneca.org/eca_resources/Publications/UNEA-Publication-toCSD15.pdf. [Accessed 12 March 2008]

[5] UNIDO 2007. Module 1: Overview of renewable energy and energy efficiency [online]. Training package on "Sustainable Energy Regulation and Policymaking for Africa". Available from: http://www.unido.org/en/doc/82315. [Accessed 17 March 2008]

[6] Anon. 2006. The Delphi method: Definition and historical background. Available from: http://www.iit.edu/ it/delphi.html. [Accessed 25 April 2007]

[7] Crichter, C. \& Gladstone, B. 1998. Utilising the Delphi technique in policy discussion: A case study of a privatised utility in Britain. Public Administration, 76 (Autumn), 431-449.

[8] Mullen, P.M. 2003. Delphi: Myths and reality. Journal of Health Organisation and Management, 17 (1), 37-52.

[9] Turoff, M. 1970. The design of a policy Delphi. Technological Forecasting and Social Change, 2 (1970), 149-171.

[10] Hasson, F., Keeney, S. \& McKenna, H. 2000. Research guidelines for the Delphi survey technique. Journal of Advanced Nursing, 32(4), 1008-1015.

[11] Boynton, L.A. 2006. What we value: A Delphi study to identify key values that guide ethical decision-making in public relations. Public Relations Review, 32 (2006, 325330.

[12] SurveyMonkey.com. The simple way to create surveys [online]. Available from: http:/ / www.surveymonkey.com. [Accessed 30 January 2007]

[13] Griffith, L.E., Hogg-Johnson, S., Cole, D.C., Krause, N., Hayden, J. Burdorf, A., Leclerc, A., Coggon, D. Bongers, P., Walter, S.D. and Shannon, H.S. 2006. Lowback pain definitions in occupational studies were categorised for a meta-analysis using Delphi consensus methods. Journal of Clinical Epidemiology, 2006, 1-9, Article in press.

[14] Okoli, C. \& Pawlowski, S.D. 2004. The Delphi method as a research tool: An example, design considerations and applications. Information and Management, 42 (2004), 15-29.

[15] Miro, J., Nieto, R. and Huguet, A. 2007. Predictive factors of chronic pain and disability in whiplash. European Journal of Pain, doi:10.1016/j.ejpain.2007.02.004. 
[16] Sackman, H. 1974. Delphi assessment: Expert opinion, forecasting and group process. Rand Report, R1283-PR, Santa Monica, CA.

[17] Cantrill, J.A., Sibbald, B. \& Buetow, S. 1998. Indicators of the appropriateness of long term prescribing in general practice in the United Kingdom: Consensus development, face and content validity, feasibility and reliability. Quality in Health Care, 7 (1998), 130-135.

[18] Alberts, D.J. 2007. Stakeholders or subject matter experts, who should be consulted? Energy Policy, 35 (2007) 2336-2346.

[19] Wild, C. \& Torgersen, H. 2000. Foresight in medicine: Lessons from three European Delphi studies. European Journal of Public Health, 10 (2), 114-119.

[20] Delbecq, A.L., Van de Ven, A.H. \& Gustafson, D.H. 1975. Group techniques for program planning: A guide to nominal group and Delphi processes. Scott, Foresman and Company.

[21] Bijl, R. 1992. Delphi in a future scenario study on mental health and mental health care. Futures, 24(3), 232-250.

[22] ESOMAR 2005. ESOMAR guideline on conducting market and opinion research using the internet. Available from:

http://www.esomar.org/uploads/pdf/ESOMAR_Codes\&Guidelines_Internet_v6.pdf. [Accessed 6 May 2007]

[23] Jillson, I.A. 1975. The national drug-abuse policy Delphi: Progress report and findings to date. In: Kumaraswamy, M.M. and Anvuur, A.M., 2007.

[24] Ishikawa, A. 1993. The new fuzzy Delphi method: Economisation of group decision support., Proceedings of the twenty sixth Hawai International Conference on System Sciences.

[25] Landeta, J. 2006. Current validity of the Delphi method in social sciences. Technological Forecasting and Social Change, 73 (2006) 467-482.

[26] Dillman, D.A. 2007. Mail and internet surveys: The tailored design method. John Wiley \& Sons, Inc, Hoboken, New Jersey, USA.

[27] Gibson, L.J. \& Miller, M.M. 1990. Delphi model for planning “preemptive” regional economic diversification. Economic Development Review, 8 (2), 34-41.

[28] Schmidt, R.C. 1997. Managing Delphi surveys using non-parametric statistical techniques. Decision Sciences, 28 (3), 763-774).

[29] Kumaraswamy, M.M. and Anvuur, A.M. 2007. Selecting sustainable teams for PPP projects. Building and Environment, doi:10.1016/j.buildenv.2007.02.001. 